\title{
Effect of fasting and of methionine deficiency on L-methionine, DL-methionine and DL-2-hydroxy-4-methylthiobutanoic acid metabolism in broiler chicks
}

\author{
BY C. LINDA SAUNDERSON \\ AFRC Institute of Grassland and Animal Production, Poultry Division, Roslin, \\ Midlothian EH25 9PS
}

(Received 24 November 1986 - Accepted 5 January 1987)

\begin{abstract}
1. Metabolism of $\mathrm{L}-\left[1-{ }^{14} \mathrm{C}\right]$ methionine, DL- $\left[1-{ }^{14} \mathrm{C}\right]$ methionine and DL-[1-14 $\left.\mathrm{C}\right] 2$-hydroxy-4-methylthiobutanoic acid (DL-HMB) by broiler chicks which had been fasted overnight or given a methionine-deficient diet was compared with fed (control) birds.

2. The excretion of ${ }^{14} \mathrm{C}$-labelled material, total ${ }^{14} \mathrm{CO}_{2}$ exhaled, ${ }^{14} \mathrm{C}$ incorporation into tissue proteins and the ${ }^{14} \mathrm{C}$-labelled material in perchloric-acid-soluble tissue fractions were measured $6 \mathrm{~h}$ after injection of the ${ }^{14} \mathrm{C}$-labelled materials.

3. The incorporation of ${ }^{14} \mathrm{C}$ into tissue proteins and the relative rates of conversion of $\mathrm{D}$-methionine and DL-HMB to L-methionine in tissues under different nutritional regimens were compared using protein-bound ${ }^{14} \mathrm{C}$ : protein-free ${ }^{14} \mathrm{C}$ values.

4. Fasted birds exhaled more ${ }^{14} \mathrm{CO}_{2}$ than control birds but excreted less ${ }^{14} \mathrm{C}$, while methionine-deficient birds behaved very similarly to the control animals in these respects.

5. Fasted birds incorporated much less ${ }^{14} \mathrm{C}$ into proteins of tissues other than liver and kidney from all three labelled tracers. The values for protein-bound ${ }^{14} \mathrm{C}$ : protein-free ${ }^{14} \mathrm{C}$ were lower in all tissues.

6. Methionine-deficient birds had similar levels of ${ }^{14} \mathrm{C}$ in tissue proteins but lower values for protein bound ${ }^{14} \mathrm{C}$ : protein-free ${ }^{14} \mathrm{C}$.

7. Examination of the values for protein-bound ${ }^{14} \mathrm{C}$ :protein-free ${ }^{14} \mathrm{C}$ suggest that brain and probably liver tissues from fasted and methionine-deficient birds showed improved rates of conversion of $D$-methionine and DL-HMB to L-methionine compared with control animals.
\end{abstract}

DL-Methionine or DL-2-hydroxy-4-methylthiobutanoic acid (DL-HMB) are commonly added to poultry feeds that are low in natural L-methionine to satisfy the requirement of the bird for this amino acid. The metabolism of these materials by normal well-fed broiler chicks has been compared and the results have been described (Saunderson, 1985). It was found that neither DL-methionine nor DL-HMB were used as efficiently as L-methionine for protein synthesis in tissues other than liver and kidney.

Since both DL-methionine and DL-HMB are generally evaluated and used when the basal diet is deficient in L-methionine, it is of interest to examine whether they are used more efficiently by birds under conditions of nutritional stress. Consequently the metabolism of all three compounds has been compared in birds which were fasted for a short period $(16 \mathrm{~h})$ and birds which were given a diet deficient in methionine. Some results from the previous paper (Saunderson, 1985) are included in the tables in the present paper to make the comparisons clearer.

\section{MATERIALS AND METHODS}

All chemicals and radiochemicals used were obtained as described previously (Saunderson, 1985).

\section{Animals and husbandry}

Broiler chicks (1 d old) were obtained from D. B. Marshall Ltd, Newbridge, Midlothian or from stock produced at the Poultry Research Centre. 
All birds were housed in a heated battery brooder and given free access to water at all times. Food was given ad lib. except during fasting, when the food was removed $16 \mathrm{~h}$ before the experiment started. Broiler chicks used for experiments with the low-methionine diet were given the conventional chick starter ration until $7 \mathrm{~d}$ old, then given the low-methionine ration until used for experiment (13-30 d old).

\section{Diets}

Two diets were used in the present study, chick starter ration (Bolton \& Blair, 1974) and a low-methionine ration. The low-methionine ration consisted of $(\mathrm{g} / \mathrm{kg})$ maize 364 , soya-bean meal 97, isolated soya-bean protein (FP950) 73, herring meal 12, maize oil 36.5, cellulose 121 , glucose $242 \cdot 6$, starch 5 , dicalcium phosphate 28 , limestone 12 , sodium chloride $2 \cdot 5$, choline chloride $1 \cdot 2$. Vitamins and minerals were added according to Bolton \& Blair (1974) for starting chicks. Chemical analysis showed this diet to contain $(\mathrm{g} / \mathrm{kg}) 160$ crude protein (nitrogen $\times 6.25$ by Kjeldhal procedure), 304 available carbohydrate and 1.97 methionine as determined by Moore oxidation procedure (Moore, 1963).

\section{Experimental procedure}

Three groups of birds were examined: normal fed, fasted overnight and methioninedeficient. Injection of radiolabelled materials, use of the metabolism chamber and measurement of ${ }^{14} \mathrm{C}$-labelled material in excreta, ${ }^{14} \mathrm{CO}_{2}$ exhaled, ${ }^{14} \mathrm{C}$ incorporation into tissue proteins and perchloric-acid (PCA)-soluble fractions were carried out as described previously (Saunderson, 1985).

\section{Statistical analysis}

The ${ }^{14} \mathrm{C}$ incorporation into tissue protein and the conversion rates of $\mathrm{D}$-methionine and DL-HMB to L-methionine produced by the different nutritional states were compared by examination of the ratio, ${ }^{14} \mathrm{C}$ bound in tissue protein: ${ }^{14} \mathrm{C}$ in PCA-soluble fraction.

Values of $\log \left(\right.$ total ${ }^{14} \mathrm{C}$ : free ${ }^{14} \mathrm{C}$ ), i.e. $\log \left(1+\left(\right.\right.$ bound ${ }^{14} \mathrm{C}$ : free $\left.{ }^{14} \mathrm{C}\right)$ ), were compared by analysis of variance. These values were approximately normally distributed when tested against normal scores (Filliben, 1975). Also, the variances of the labelled material $\times$ dietary status combinations were similar.

Comparison of the effect of treatment (administration of $\mathrm{L}-\left[1-{ }^{14} \mathrm{C}\right] \mathrm{methionine,} \mathrm{DL-}$ $\left[1-{ }^{14} \mathrm{C}\right]$ methionine or $\mathrm{DL}-\left[1-{ }^{14} \mathrm{C}\right] \mathrm{HMB}$ and overnight fasting or rearing on a methioninedeficient diet) on excretion and ${ }^{14} \mathrm{CO}_{2}$ released was also made by analysis of variance. The analyses were performed on the log scale to give better approximations to normality and constant variance.

\section{RESULTS}

In all experiments, the source of 1 d old chicks, the age of the birds used and body-weight did not affect the results.

The release of ${ }^{14} \mathrm{CO}_{2}$ by birds given the $\mathrm{L}-$ or DL- $\left[1-{ }^{14} \mathrm{C}\right]$ methionine or DL- $\left[1-{ }^{14} \mathrm{C}\right] \mathrm{HMB}$ is shown in Table 1. Birds had been fed ad lib. (control), fasted overnight, or reared on the low-methionine ration.

Fasted birds showed an increase in the proportion of all three materials oxidized to ${ }^{14} \mathrm{CO}_{2}$. This difference was statistically significant $(P<0.001)$. The increased oxidation of DL-methionine compared with L-methionine and DL-HMB found in fed birds (Table 1; Saunderson, 1985) is also evident in fasted and methionine-deficient birds. There was more oxidation of $\mathrm{DL}\left[1-{ }^{14} \mathrm{C}\right]$ methionine than the other two tracers; differences on the log scale being $0 \cdot 22$ (SE $0 \cdot 10)$ and $0 \cdot 28(\operatorname{SE~} 0 \cdot 11)$. 
Table $1 .{ }^{14} \mathrm{CO}_{2}$ exhaled and ${ }^{14} \mathrm{C}$ in excreta of chicks $6 \mathrm{~h}$ after administration of $L_{-}$

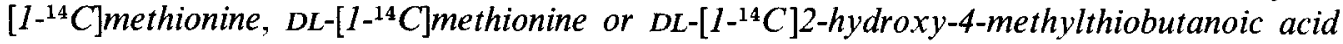
$\left(D L-\left[1-{ }^{14} C\right] H M B\right)$

(Values are means with corresponding values of $\log { }^{14} \mathrm{C}$ exhaled and $\log { }^{14} \mathrm{C}$ excreted in parentheses)

\begin{tabular}{|c|c|c|c|}
\hline $\begin{array}{l}\text { Nutritional state } \\
\text { and treatment }\end{array}$ & $n$ & $\begin{array}{c}{ }^{14} \mathrm{CO}_{2} \text { produced } \\
(\% \text { dose })\end{array}$ & $\begin{array}{c}{ }^{14} \mathrm{C} \text { in excreta } \\
(\% \text { dose })\end{array}$ \\
\hline \multicolumn{4}{|l|}{ Control } \\
\hline $\mathrm{L}-\left[1-{ }^{14} \mathrm{C}\right]$ methionine & 8 & $4 \cdot 27(1 \cdot 40)$ & $1.88(0.62)$ \\
\hline DL- $\left[1-{ }^{14} \mathrm{C}\right]$ methionine & 8 & $5.51(1.70)$ & $9 \cdot 59(2.25)$ \\
\hline DL- $\left[1-{ }^{14} \mathrm{C}\right] \mathrm{HMB}$ & 8 & $5.04(1.55)$ & $20.99(3.04)$ \\
\hline \multicolumn{4}{|l|}{ Fasted } \\
\hline $\mathrm{L}-\left[1-{ }^{14} \mathrm{C}\right]$ methionine & 10 & $7.04(1.97)$ & $1 \cdot 23(0 \cdot 12)$ \\
\hline DL- $\left[1-{ }^{14} \mathrm{C}\right]$ methionine & 4 & $9 \cdot 56(2.22)$ & $7 \cdot 59(2.01)$ \\
\hline DL- $\left[1-{ }^{14} \mathrm{C}\right] \mathrm{HMB}$ & 6 & $5.84(1.71)$ & $19.71(2.97)$ \\
\hline \multicolumn{4}{|l|}{ Methionine-deficient } \\
\hline $\mathrm{L}-\left[1-{ }^{14} \mathrm{C}\right]$ methionine & 4 & $4.41(1.42)$ & $2 \cdot 91(1 \cdot 06)$ \\
\hline DL- $\left[1{ }^{14} \mathrm{C}\right]$ methionine & 4 & $4.92(1.54)$ & $11 \cdot 15(2 \cdot 39)$ \\
\hline $\mathrm{DL}-\left[1-{ }^{14} \mathrm{C}\right] \mathrm{HMB}$ & 4 & $3 \cdot 70(1 \cdot 30)$ & $21.53(3.07)$ \\
\hline Pooled SD & & $(0 \cdot 31)$ & $(0.23)$ \\
\hline
\end{tabular}

Table 1 also shows excretion of ${ }^{14} \mathrm{C}$ by birds on the three different nutritional regimens. There were large differences betwen the three ${ }^{14} \mathrm{C}$-labelled tracers $(P<0.001)$ but the nutritional conditions also had a significant effect $(P<0.05)$. There was a significant interaction between nutritional status and tracer given which was largely due to the different behaviour of the three tracers under the three different nutritional regimens. The mean values for ${ }^{14} \mathrm{C}$ excretion from $\mathrm{L}-\left[1-{ }^{14} \mathrm{C}\right]$ methionine showed comparatively large differences between nutritional treatments while DL-[1-14C]HMB values showed only very small differences and $\mathrm{DL}-\left[{ }^{14} \mathrm{C}\right]$ methionine values were between the other two.

There are two ways in which nutritional state could affect the use of DL-methionine (D-methionine) and DL-HMB for tissue protein synthesis. Changes could be produced in the rates of synthesis and degradation per se (i.e. L-methionine incorporation), or in the amount of D-methionine and D- and L-HMB converted to L-methionine or both. An indication of these changes can be gained from the ${ }^{14} \mathrm{C}$ incorporated into tissue proteins, the ${ }^{14} \mathrm{C}$ in the PCA-soluble fraction of tissues and values of protein-bound ${ }^{14} \mathrm{C}: \mathrm{PCA}$-soluble ${ }^{14} \mathrm{C}$. These results are shown in Tables 2,3 and 4 respectively.

The bound ${ }^{14} \mathrm{C}$; free ${ }^{14} \mathrm{C}$ ratio for $\mathrm{L}-\left[1-{ }^{14} \mathrm{C}\right]$ methionine in each nutritional state reflects the incorporation of ${ }^{14} \mathrm{C}$ into protein (i.e. the combined effect of protein synthesis and degradation and loss of amino acid precursor); the higher the ratio the greater the incorporation. A change in the ratios for DL-methionine and DL-HMB relative to Lmethionine produced by a different nutritional state would indicate a change in the amount of D-methionine and DL-HMB converted to L-methionine.

Fasting and methionine deficiency both produced increases in ${ }^{14} \mathrm{C}$ labelling in PCAsoluble fractions of tissues for all three tracers. In methionine-deficient birds the ${ }^{14} \mathrm{C}$ appearing in tissue proteins was very similar to that in control birds whereas in fasted birds there was a considerable decrease in the ${ }^{14} \mathrm{C}$ incorporated into skeletal muscles. These differences were not the result of changes in the protein content of the tissues. When results were calculated as counts/min per mg protein, the same pattern of incorporation was evident (results not shown).

The values for protein-bound ${ }^{14} \mathrm{C}$ : PCA-soluble ${ }^{14} \mathrm{C}$ for $\mathrm{L}-\left[1-{ }^{14} \mathrm{C}\right]$ methionine (Table 4 ) 
Table 2. Incorporation of ${ }^{14} \mathrm{C}$ into tissue proteins (counts/min per $\mathrm{g}$ wet tissue) from $L-\left[1-{ }^{14} C\right]$ methionine $\left(L-\left[1-{ }^{14} C\right]\right.$ met $), D L-\left[1-{ }^{14} C\right]$ methionine $\left(D L-\left[1-{ }^{14} C\right]\right.$ met $)$ or $D L-[1-14 C] 2-$ hydroxy-4-methylthiobutanoic acid $\left(D L-\left[I^{14} C\right] H M B\right)$ under different nutritional conditions

(Values are means with their standard errors; no. of observations in parentheses)

\begin{tabular}{|c|c|c|c|c|c|c|}
\hline \multirow[b]{3}{*}{ Tissue } & \multicolumn{6}{|c|}{ Control } \\
\hline & \multicolumn{2}{|c|}{$\begin{array}{c}L-\left[1-{ }^{14} \mathrm{C}\right] \mathrm{met} \\
(8)\end{array}$} & \multicolumn{2}{|c|}{$\begin{array}{c}\text { DL- }\left[1-{ }^{14} \mathrm{C}\right] \mathrm{met} \\
(8)\end{array}$} & \multicolumn{2}{|c|}{$\begin{array}{c}\text { DL. }-\left[1-{ }^{14} \mathrm{C}\right] \mathrm{HMB} \\
(8)\end{array}$} \\
\hline & Mean & SE & Mean & $\mathrm{SE}$ & Mean & SE \\
\hline Breast muscle & 4250 & 407 & 2850 & 328 & 2220 & 153 \\
\hline Leg muscle & 4170 & 595 & 2820 & 233 & 2640 & 232 \\
\hline Liver & 11000 & 1191 & 11700 & 746 & 11700 & 946 \\
\hline Kidney & 9720 & 903 & 13000 & 776 & 10300 & 809 \\
\hline Heart muscle & 7770 & 945 & 5430 & 444 & 4850 & 249 \\
\hline Skin & 4540 & 764 & 2340 & 203 & 2040 & 137 \\
\hline \multirow[t]{3}{*}{ Brain } & 3470 & 644 & 1980 & 171 & 2040 & 163 \\
\hline & \multicolumn{6}{|c|}{ Fasted } \\
\hline & \multicolumn{2}{|c|}{$\begin{array}{c}\mathrm{L}-\left[1-{ }^{14} \mathrm{C}\right] \mathrm{met} \\
(9)\end{array}$} & \multicolumn{2}{|c|}{$\begin{array}{c}\mathrm{DL}-\left[1{ }^{14} \mathrm{C}\right] \mathrm{met} \\
(4)\end{array}$} & \multicolumn{2}{|c|}{$\begin{array}{c}\mathrm{DL}-\left[1-{ }^{14} \mathrm{C}\right] \mathrm{HMB} \\
(6)\end{array}$} \\
\hline Tissue & Mean & $\mathrm{SE}$ & Mean & SE & Mean & SE \\
\hline Breast muscle & 2340 & 407 & 1520 & 241 & 1100 & 174 \\
\hline Leg muscle & 1980 & 288 & 1960 & 363 & 1450 & 120 \\
\hline Liver & 15600 & 1760 & 14300 & 1880 & 15800 & 1426 \\
\hline Kidney & 13200 & 1466 & 16800 & 2285 & 14200 & 745 \\
\hline Heart muscle & 7230 & 724 & 5140 & 810 & 5140 & 261 \\
\hline Skin & 3000 & 422 & 2200 & 461 & 2040 & 183 \\
\hline \multirow[t]{3}{*}{ Brain } & 3500 & 353 & 2900 & 275 & 2880 & 206 \\
\hline & \multicolumn{6}{|c|}{ Methionine-deficient diet } \\
\hline & \multicolumn{2}{|c|}{$\begin{array}{c}\mathrm{L}-\left[1-{ }^{14} \mathrm{C}\right] \mathrm{met} \\
(4)\end{array}$} & \multicolumn{2}{|c|}{$\begin{array}{c}\text { DL- }\left[1-{ }^{14} \mathrm{C}\right] \mathrm{met} \\
\text { (4) }\end{array}$} & \multicolumn{2}{|c|}{$\begin{array}{c}\text { DL }-\left[1-{ }^{-14} \mathrm{C}\right] \mathrm{HMB} \\
(4)\end{array}$} \\
\hline Tissue & Mean & SE & Mean & $\mathbf{S E}$ & Mean & $\mathrm{SE}$ \\
\hline Breast muscle & 4650 & 490 & 3420 & 474 & 2530 & 256 \\
\hline Leg muscle & 4360 & 473 & 3550 & 373 & 3070 & 469 \\
\hline Liver & 11530 & 640 & 14600 & 434 & 13500 & 748 \\
\hline Kidney & 12000 & 777 & 16100 & 627 & 10600 & 1111 \\
\hline Heart muscle & 8050 & 638 & 6360 & 252 & 5700 & 259 \\
\hline Skin & 3630 & 231 & 2620 & 496 & 2150 & 311 \\
\hline Brain & 2540 & 105 & 2060 & 232 & 2200 & 195 \\
\hline
\end{tabular}

show that both fasting and methionine-deficiency produced a decrease in incorporation of ${ }^{14} \mathrm{C}$ into proteins of all tissues. Fasting also produced a decreased ratio in all tissues when DL- $\left[1-{ }^{14} \mathrm{C}\right] \mathrm{HMB}$ was given and in all tissues except brain when $\mathrm{DL}-\left[1-{ }^{14} \mathrm{C}\right]$ methionine was the tracer used. When DL-[1-14 C]methionine or DL- $\left[1-{ }^{14} \mathrm{C}\right] \mathrm{HMB}$ was given to methioninedeficient birds the ratio in liver and skin tissues was increased compared with control birds (Table 4). There were also differences between control and fasted or methionine-deficient birds when comparing the value for protein-bound ${ }^{14} \mathrm{C}:{ }^{14} \mathrm{C}$ in the free pool for $\mathrm{L}$ - 
Table $3 .{ }^{14} \mathrm{C}$-labelling in perchloric acid-soluble tissue fractions (counts/min per $g$ wet tissue) from $L-\left[1-{ }^{14} C\right]$ methionine $\left(L-\left[1-{ }^{14} C\right] m e t\right), D L-\left[1-{ }^{14} C\right] m e t h i o n i n e ~\left(D L-\left[1-{ }^{14} C\right] m e t\right)$ or $D L-\left[1-{ }^{14} C\right] 2-h y d r o x y-4-m e t h y l t h i o b u t a n o i c$ acid $\left(D L-\left[1-{ }^{14} C\right] H M B\right)$ under different nutritional conditions

(Values are means with their standard errors; no. of observations in parentheses)

\begin{tabular}{|c|c|c|c|c|c|c|}
\hline \multirow[b]{3}{*}{ Tissue } & \multicolumn{6}{|c|}{ Control } \\
\hline & \multicolumn{2}{|c|}{$\begin{array}{c}\mathrm{L}-\left[1-{ }^{14} \mathrm{C}\right] \mathrm{met} \\
(8)\end{array}$} & \multicolumn{2}{|c|}{$\begin{array}{c}\mathrm{DL}-\left[1-{ }^{-14} \mathrm{C}\right] \mathrm{met} \\
(8)\end{array}$} & \multicolumn{2}{|c|}{$\begin{array}{c}\text { DL- }\left[1-{ }^{14} \mathrm{C}\right] \mathrm{HMB} \\
(8)\end{array}$} \\
\hline & Mean & SE & Mean & $\mathrm{SE}$ & Mean & SE \\
\hline Breast muscle & 500 & 56 & 590 & 58 & 520 & 38 \\
\hline Leg muscle & 590 & 50 & 800 & 60 & 610 & 35 \\
\hline Liver & 1670 & 160 & 2330 & 195 & 2150 & 106 \\
\hline Kidney & 1750 & 202 & 3230 & 305 & 1910 & 134 \\
\hline Heart muscle & 640 & 55 & 700 & 66 & 610 & 30 \\
\hline Skin & 820 & 83 & 970 & 84 & 920 & 68 \\
\hline \multirow[t]{3}{*}{ Brain } & 420 & 25 & 600 & 56 & 420 & 28 \\
\hline & \multicolumn{6}{|c|}{ Fasted } \\
\hline & \multicolumn{2}{|c|}{$\begin{array}{c}\mathrm{L}-\left[1-{ }^{14} \mathrm{C}\right] \mathrm{met} \\
(9)\end{array}$} & \multicolumn{2}{|c|}{$\begin{array}{c}\mathrm{DL}-\left[1-{ }^{14} \mathrm{C}\right] \mathrm{met} \\
(4)\end{array}$} & \multicolumn{2}{|c|}{$\begin{array}{c}\text { DL- }\left[1-{ }^{14} \mathrm{C}\right] \mathrm{HMB} \\
(6)\end{array}$} \\
\hline Tissue & Mean & $\mathrm{SE}$ & Mean & $\mathrm{SE}$ & Mean & $\mathbf{S E}$ \\
\hline Breast muscle & 1100 & 107 & 1180 & 64 & 760 & 21 \\
\hline Leg muscle & 1170 & 73 & 1330 & 34 & 850 & 34 \\
\hline Liver & 4640 & 491 & 4470 & 275 & 4340 & 374 \\
\hline Kidney & 6190 & 960 & 7300 & 1202 & 4320 & 339 \\
\hline Heart muscle & 1360 & 71 & 1550 & 154 & 1070 & 47 \\
\hline Skin & 1550 & 103 & 1690 & 115 & 1330 & 137 \\
\hline \multirow[t]{3}{*}{ Brain } & 980 & 31 & 1030 & 64 & 760 & 27 \\
\hline & \multicolumn{6}{|c|}{ Methionine-deficient diet } \\
\hline & \multicolumn{2}{|c|}{$\begin{array}{c}\mathrm{L}-\left[1-{ }^{14} \mathrm{C}\right] \mathrm{met} \\
(4)\end{array}$} & \multicolumn{2}{|c|}{$\begin{array}{c}\mathrm{DL}-\left[1{ }^{14} \mathrm{C}\right] \mathrm{met} \\
(4)\end{array}$} & \multicolumn{2}{|c|}{$\begin{array}{c}\mathrm{DL}-\left[1-{ }^{14} \mathrm{C}\right] \mathrm{HMB} \\
(4)\end{array}$} \\
\hline Tissue & Mean & $\mathbf{S E}$ & Mean & $\mathrm{SE}$ & Mean & $\mathrm{SE}$ \\
\hline Breast muscle & 850 & 111 & 840 & 59 & 800 & 32 \\
\hline Leg muscle & 940 & 88 & 1040 & 111 & 910 & 61 \\
\hline Liver & 2630 & 533 & 2770 & 224 & 2630 & 568 \\
\hline Kidney & 3030 & 473 & 5070 & 178 & 2460 & 350 \\
\hline Heart muscle & 900 & 130 & 700 & 202 & 900 & 90 \\
\hline Skin & 1260 & 296 & 1150 & 330 & 940 & 47 \\
\hline Brain & 670 & 56 & 690 & 69 & 680 & 62 \\
\hline
\end{tabular}

$\left[1-{ }^{14} \mathrm{C}\right]$ methionine with those for the other two materials. The lower ratios found for DL- $\left[1-{ }^{14} \mathrm{C}\right]$ methionine and DL- $\left[1-{ }^{14} \mathrm{C}\right] \mathrm{HMB}$ in control birds were not evident in liver, kidney and brain of methionine-deficient birds or in liver, kidney, heart, skin and brain of fasted birds (Table 4).

When values were examined by analysis of variance (Table 5), liver and kidney tissues showed no effect of methionine tracer administered while all other tissues showed a highly significant effect. The differences in the ratios for brain tissue under different nutritional 
Table 4. Mean values of protein-bound ${ }^{14} \mathrm{C}:{ }^{14} \mathrm{C}$ in the free pool for tissues of birds under different nutritional conditions given $L-\left[1-{ }^{14} \mathrm{C}\right]$ methionine $\left(L-\left[1-{ }^{14} \mathrm{C}\right]\right.$ met $), D L-\left[1-{ }^{14} \mathrm{C}\right]$ methionine $\left(D L-\left[1-{ }^{14} C\right]\right.$ met $)$, or $D L-\left[1-{ }^{14} C\right] 2-$ hydroxy-4-methylthiobutanoic acid $\left(D L-\left[1-{ }^{14} C\right] H M B\right)$

(Values are means with corresponding values of $\log$ (total ${ }^{14} \mathrm{C}:{ }^{14} \mathrm{C}$ in the free pool) in parentheses)

\begin{tabular}{|c|c|c|c|}
\hline Tissue & L- $\left[1-{ }^{14} \mathrm{C}\right] \mathrm{met}$ & DL- $\left[1-^{14} \mathrm{C}\right] \mathrm{met}$ & DL- $\left[1-{ }^{14} \mathrm{C}\right] \mathrm{HMB}$ \\
\hline $\begin{array}{l}\text { Breast muscle } \\
\text { Leg muscle } \\
\text { Liver } \\
\text { Kidney } \\
\text { Heart muscle } \\
\text { Skin } \\
\text { Brain }\end{array}$ & $\begin{array}{r}8.6(2.26) \\
6.8(2.05) \\
6.7(2.04) \\
5.7(1.90) \\
11.4(2.52) \\
5.3(1.84) \\
8.0(2.19)\end{array}$ & $\begin{array}{c}\text { Control } \\
4 \cdot 8(1 \cdot 75) \\
3 \cdot 5(1.51) \\
5 \cdot 1(1.81) \\
4 \cdot 1(1.64) \\
7 \cdot 8(2 \cdot 18) \\
2.4(1.24) \\
3 \cdot 0(1.40)\end{array}$ & $\begin{array}{l}4.3(1.67) \\
4.3(1.67) \\
5.4(1.85) \\
5.4(1.86) \\
7.9(2.19) \\
2.2(1.16) \\
4.8(1.77)\end{array}$ \\
\hline No. of birds & 8 & 8 & 8 \\
\hline $\begin{array}{l}\text { Breast muscle } \\
\text { Leg muscle } \\
\text { Liver } \\
\text { Kidney } \\
\text { Heart muscle } \\
\text { Skin } \\
\text { Brain }\end{array}$ & $\begin{array}{l}2.0(1.11) \\
2.0(1.10) \\
3.4(1.48) \\
2.7(1.31) \\
5.2(1.83) \\
1.9(1.06) \\
3.5(1.50)\end{array}$ & $\begin{array}{c}\text { Fasted } \\
1.3(0.82) \\
1.4(0.89) \\
3 \cdot 2(1.42) \\
2.4(1.23) \\
3.3(1.46) \\
1.3(0.81) \\
3 \cdot 0(1.40)\end{array}$ & $\begin{array}{l}1.4(0.88) \\
1.7(0.99) \\
4.2(1.64) \\
3.4(1.47) \\
4.8(1.76) \\
1.6(0.95) \\
3.8(1.57)\end{array}$ \\
\hline No. of birds & 9 & 4 & 6 \\
\hline $\begin{array}{l}\text { Breast muscle } \\
\text { Leg muscle } \\
\text { Liver } \\
\text { Kidney } \\
\text { Heart muscle } \\
\text { Skin } \\
\text { Brain }\end{array}$ & $\begin{array}{l}\quad M \\
5.6(1.88) \\
4.7(1.74) \\
3 \cdot 3(1.55) \\
4 \cdot 1(1.63) \\
9 \cdot 2(2.32) \\
4 \cdot 3(1.66) \\
3.9(1.58)\end{array}$ & $\begin{array}{c}\text { hionine-deficien } \\
4.0(1.62) \\
3.3(1.45) \\
5.3(1.85) \\
3.2(1.43) \\
6.7(2.05) \\
2.5(1.26) \\
2.7(1.32)\end{array}$ & $\begin{array}{l}\text { diet } \\
\qquad \begin{array}{l}2.7(1.32) \\
3.3(1.45) \\
6.3(1.98) \\
4.4(1.68) \\
6.4(2.00) \\
2.3(1.18) \\
3.3(1.45)\end{array}\end{array}$ \\
\hline No. of birds & 4 & 4 & 4 \\
\hline
\end{tabular}

Table 5. Statistical comparisons for values of $\log$ (protein-bound ${ }^{14} \mathrm{C}:{ }^{14} \mathrm{C}$ in free pool), residual mean squares (RMS), degrees of freedom and corresponding $\mathrm{F}$ values for form of $\left[{ }^{14} \mathrm{C}\right]$ methionine given, nutritional state and the interaction

( $F$ values are compared with the $F$ distribution on $F_{4,40}$ for the interaction of $F_{2,40}$ for the methionine source and nutritional status; values are $F_{4,40}: P<0.052 .6, P<0.013 .8, P<0.0015 .7 ; F_{2,40}$ : $P<0.053 .2, P<0.015 .2, P<0.0018 .3$ )

\begin{tabular}{lccccc}
\hline \hline & & & \multicolumn{4}{c}{$F$ value } \\
\cline { 4 - 6 } \multicolumn{1}{c}{ Tissue } & RMS & df & $\begin{array}{c}\text { Methionine } \\
\text { source }\end{array}$ & $\begin{array}{c}\text { Nutritional } \\
\text { state }\end{array}$ & Interaction \\
\hline Breast muscle & 0.0860 & 46 & $12 \cdot 58^{* * *}$ & $60 \cdot 10^{* * *}$ & $0 \cdot 95$ \\
Leg muscle & 0.0796 & 46 & $8 \cdot 53^{* * *}$ & $40 \cdot 53^{* * *}$ & $1 \cdot 51$ \\
Liver & 0.0688 & 46 & 0.79 & $11 \cdot 17^{* * *}$ & $2 \cdot 26$ \\
Kidney & 0.0646 & 46 & $3 \cdot 19$ & $17 \cdot 85^{* * *}$ & $0 \cdot 71$ \\
Heart muscle & 0.0583 & 46 & $9 \cdot 11^{* * *}$ & $33 \cdot 84^{* * *}$ & 0.99 \\
Skin & 0.1155 & 46 & $9 \cdot 74^{* * *}$ & $12 \cdot 32^{* * *}$ & $1 \cdot 38$ \\
Brain & 0.0642 & 44 & $12 \cdot 21^{* * *}$ & $11 \cdot 04^{* * *}$ & $4 \cdot 02^{* * *}$ \\
\hline \hline
\end{tabular}


states appeared as a significant interaction. Liver tissue was close to showing a significant effect $(0.05>P<0 \cdot 10)$ in the interaction.

\section{DISCUSSION}

Fasting birds for a short period before administration of DL-[1-14 C]HMB, DL-[1$\left.{ }^{14} \mathrm{C}\right]$ methionine or $\mathrm{L}-\left[1-{ }^{14} \mathrm{C}\right]$ methionine produced an increase in ${ }^{14} \mathrm{CO}_{2}$ exhaled but a decrease in excreta ${ }^{14} \mathrm{C}$. That all three tracers (to a greater or lesser degree) change in the same way indicates that this is a general adaptation to short-term fasting. The decreased excretion of ${ }^{14} \mathrm{C}$ by fasted birds (especially of L-methionine) suggests that there is increased reabsorption of potentially useful material in the proximal tubule of the kidney. Again this is a general reaction to fasting and probably reflects lower plasma levels of excreted metabolites.

That changes in excretion between nutritional states are greatest with $L-\left[1-{ }^{14} \mathrm{C}\right]$ methionine and least with DL- $\left[1-{ }^{14} \mathrm{C}\right] \mathrm{HMB}$ suggests that the bird has relatively little capacity to change the excretion of DL-HMB (or D-methionine) but can adjust the excretion of L-methionine readily under different nutritional conditions.

The increase in ${ }^{14} \mathrm{C}$ in the PCA-soluble tissue fractions from fasted birds (especially in liver and kidney) equates well with the increased proportion of the three tracers oxidized under such conditions. Oxidation is a route for disposal of excess methionine in rats (Aquilar et al. 1974) and in pigs (Kim \& Bayley, 1983). It is likely that chicks also dispose of unused methionine by oxidation but two mechanisms could operate in such a system. Either the enzymes in the oxidation pathway become more active in fasted birds, or the pool of methionine available for oxidation is greater, producing an increased flux through the pathway. In this case, the increased ${ }^{14} \mathrm{CO}_{2}$ may actually represent a lower oxidation of total methionine, although it is difficult to say without accurate measurements of the specific activity of the methionine pool used for oxidation.

In the methionine-deficient birds the increased ${ }^{14} \mathrm{C}$ in the PCA-soluble fraction did not result in an increased amount of ${ }^{14} \mathrm{C}$ precursors being oxidized. It is possible that the oxidation pathway is less active in birds given a diet low in methionine. Aquilar et al. (1974) found that increasing methionine in the diet increased methionine oxidation. Presumably the converse will also be true.

Fasting and methionine deficiency produce different conditions of methionine supply in the tissues. Protein breakdown during fasting will release methionine (and all other amino acids) which can be considered as excess to requirement. On the other hand, birds given a methionine-deficient diet will have a lower amount of this amino acid for protein synthesis compared with the other dietary amino acids. Thus, during fasting the tissues will require to dispose of methionine while during deficiency they will require to conserve it.

Nevertheless it is interesting that both fasting and methionine deficiency lead to increased ${ }^{14} \mathrm{C}$ labelling in the PCA-soluble fractions. This suggests that a complex mechanism of control exists over the fate of L-methionine within the cell under different nutritional conditions. One way in which such a control might operate is suggested by Cooper (1983), who postulates that the interconversion of L-methionine and 2-keto-4-methylthiobutanoic acid (KMB) is catalysed by a different transaminase enzyme in each direction. This would allow separate control mechanisms to operate for conserving KMB when methionine supply was low and for oxidation of L-methionine when this was 'excess' to requirements.

Differences in ${ }^{14} \mathrm{C}$ appearing in tissue proteins (or more accurately in the ratio, bound ${ }^{14} \mathrm{C}:{ }^{14} \mathrm{C}$ in the free pool) are due to either changes in the rates of protein synthesis or degradation or both, or to changes in the rates of conversion of D-methionine and D- and $\mathrm{L}-\mathrm{HMB}$ to $\mathrm{L}$-methionine. Changes produced in $\mathrm{L}-\left[1-{ }^{14} \mathrm{C}\right]$ methionine incorporation under 
different nutritional regimens are due to changes in protein synthesis/degradation. The causes of differences in ${ }^{14} \mathrm{C}$ in protein when $\mathrm{DL}-\left[1-{ }^{14} \mathrm{C}\right]$ methionine or DL- $\left[1-{ }^{14} \mathrm{C}\right] \mathrm{HMB}$ are given to fasted or methionine-deficient birds are much more complex, but certainly involve changes in the rates of conversion of D-methionine and D- and L-HMB to L-methionine. However, since these experiments were carried out in vivo (to follow oxidation and excretion) the information on labelling in tissue components is not extensive enough to quantify the contribution of the various effects to the differences in ${ }^{14} \mathrm{C}$ incorporation into proteins in all tissues. In order to study such possibilities, rates of oxidation, excretion and protein turnover in individual tissues in vitro would be necessary. This was outside the scope of the present study but along with studies on oxidation and conversion enzymes will be the subject of future work.

The significant interaction between $\left[{ }^{14} \mathrm{C}\right]$ methionine tracer given and nutritional state in brain and liver tissues (Table 5) implies that, in these tissues, the conversion of D-methionine and D- and L-HMB to L-methionine or their utilization for protein synthesis is improved under conditions of nutritional stress. This finding is most interesting. Excess D-methionine in the diet of chicks does not induce an increased activity of the D-amino acid oxidase in liver or kidney (Bauriedel, 1963). It is not known whether methionine deficiency or fasting affect the activity of this enzyme. Marrett \& Sunde (1965) found that the utilization of D-methionine could be altered by the presence of other D-amino acids in the diet (especially D-valine). They suggest that in this situation, the D-amino acid oxidase is overloaded.

There are two enzymes catalysing the conversion of DL-HMB to the keto acid (KMB), one specific for each stereoisomer (Dibner \& Knight, 1984). These enzymes have a broad specificity and do not appear to be inducible by HMB in the diet (Langer, 1965). Both enzymes are active in the liver and kidney of chicks but D-hydroxy acid dehydrogenase activity is also found in a number of other tissues including red muscle, small intestine and brain (Dibner \& Knight, 1984). Work in this laboratory (C. L. Saunderson, unpublished results) has found that chick brain tissue readily oxidizes DL-HMB in vitro confirming the activity of at least one of the enzymes in this tissue. The presence of this enzyme activity may lead to increased efficiency of utilization of DL-HMB in brain during fasting and methionine deficiency.

The background evidence from the present study and the work of Dibner \& Knight (1984) agree well with a nutritional study reported by Baker \& Boebel (1980). These authors found that D-HMB was a more effective source of sulphur amino acid activity than L-HMB in chicks given methionine-deficient soya-bean protein or crystalline-amino-acid-based diets.

Conversion of D-methionine and D- and L-HMB to L-methionine is also dependent on the transamination of the intermediate 2-keto acid (KMB). Cooper (1983) suggested that this reaction is catalysed in vivo by glutamine-pyruvate aminotransferase $(E C 2.6 .1$.15) but little is known of the tissue distribution, specificity or regulation of the enzyme when KMB is the substrate (Cooper \& Meister, 1981). Although this enzyme might be considered to be more abundant in tissues than either the D-amino acid oxidase or D- and L-hydroxy acid dehydrogenase systems, it could nevertheless have a controlling influence on the flux through the pathway (McMinn \& Ottaway, 1976).

Change in efficiency of conversion of D-methionine or D- and L-HMB to L-methionine does not necessarily require a change in the activity of either or both enzymes involved. Only an increased flux is indicated and this can be produced by increased levels of the substrates, intermediates or cofactors involved. This could also be a cause of the differing responses in different tissues.

In conclusion it would appear that while D-methionine and DL-HMB are inferior to L-methionine as a source of supplemental methionine in the diet, there are circumstances 
where these analogues can be more effectively used by the bird. However, the improvement in utilization of D-methionine and DL-HMB in fasted and methionine-deficient birds found in the present study is not extensive and the majority of tissues show no increase in incorporation of ${ }^{14} \mathrm{C}$ from $\mathrm{DL}-\left[1-{ }^{14} \mathrm{C}\right] \mathrm{HMB}$ and $\mathrm{DL}-\left[1-{ }^{14} \mathrm{C}\right]$ methionine into tissue proteins.

The author would like to express thanks to Dr F. J. Ivey, Monsanto Company, St. Louis, Missouri, USA for the very kind gift of DL-[1- $\left.{ }^{14} \mathrm{C}\right] \mathrm{HMB}$, and to Dr C. Fisher for helpful discussion of this work. Appreciation is also extended to $\mathrm{Mr} \mathrm{S}$. Leslie and $\mathrm{Mr} \mathrm{D}$. Greenhill for excellent technical assistance, to $\mathrm{Mr} \mathrm{L}$. Broadbent for diet formulation and to $\mathrm{Mr}$ D. Waddington for guidance on statistical analyses.

\section{REFERENCES}

Aquilar, T. S., Benevenga, N. J. \& Harper, A. E. (1974). Journal of Nutrition 104, 761-771.

Baker, B. H. \& Boebel, K. P. (1980). Journal of Nutrition 110, 959-964.

Bauriedel, W. R. (1963). Poultry Science 42, 214-217.

Bolton, W. \& Blair, R. (1974). Poultry Nutrition Bulletin no. 174, 4th ed. London: H. M. Stationery Office.

Cooper, A. J. L. (1983). Annual Review of Biochemistry 52, 187-222.

Cooper, A. J. L. \& Meister, A. (1981). Comparative Biochemistry and Physiology 69B, 137-145.

Dibner, J. J. \& Knight, C. D. (1984). Journal of Nutrition 114, 1716-1723.

Filliben, J. J. (1975). Technometrics 14, 111-116.

Kim, K. I. \& Bayley, H. S. (1983). British Journal of Nutrition 50, 383-390.

Langer, B. W. (1965). Biochemical Journal 95, 683-687.

McMinn, C. L. \& Ottaway, J. H. (1976). Journal of Theoretical Biology 56, 57-73.

Marrett, L. E. \& Sunde, M. L. (1965). Poultry Science 44, 957-964.

Moore, J. (1963). Journal of Biological Chemistry 238, 235-237.

Saunderson, C. L. (1985). British Journal of Nutrition 54, 621-633. 